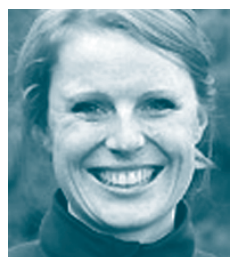

Ellen Tolo, kreftsykepleier ved kreftavdelingen på Haukeland universitetssykehus.

\title{
Kreft i Tanzania
}

\author{
Afrika er den verdensdelen med flest nye krefttilfeller. \\ Likevel har kreft kommet i skyggen av det generelle sykdomsbildet.
}

$\mathbf{K}$ reftavdelingen på Haukeland universitetssykehus har et samarbeidsprosjekt med kreftsykehuset Ocean Road Cancer Institute (ORCI), Dar es Saalam, Tanzania. I en periode jobbet jeg som sykepleier ved dette sykehuset. I denne artikkelen vil jeg belyse kreftsituasjonen i Afrika, med spesifikke innslag fra Tanzania.

\section{En klump i brystet}

En kvinne kjenner en klump i brystet. Hun bryr seg først ikke om den, og tenker at den vil forsvinne etter hvert. Men klumpen forsvinner ikke, den blir bare større. Etter en tid bestemmer hun seg for å oppsøke en lege. Det er få leger i regionen der hun bor så hun bruker en hel dag på å komme seg til legekontoret, og enda en dag på å stå $i$ kø. Når hun endelig kommer inn på kontoret gir legen henne en antibiotikakur. Til tross for antibiotikabehandlingen blir ikke kulen $i$ brystet mindre. Hun søker derfor råd hos den lokale medisinmannen. Av ham får hun noen urter. Kvinnen bruker disse urtene i noen måneder, for hun er klar over at det kan ta tid for urteblandingen å virke. Men klumpen minker ikke. Den blir tvert imot større. På dette tidspunktet har brystet økt betydelig i omfang. Det er hovent og rødt, og det har etter hvert blitt ubehagelig for kvinnen å løfte armen. Dette plager henne så mye at hun oppsøker legen på nytt. Det er en annen lege denne gangen, og han får mistanke om at det kan vore brystkreft. Denne legen henviser henne til et sykehus hvor hun kan undersøkes videre og ta en biopsi. Problemet er at det vil ta henne om lag en uke å komme dit. Det vil koste mye i reiseutgifter, å bo der, få behandling, og hvem skal ta seg av familien? Økonomisk vil det bli svcert kostbart, men hun er heldig og har en stor familie som samler sammen nok penger til at hun kan reise. Regionsykehuset hun reiser til er et av de få sykehusene som har en patolog som kan ta biopsi og analysere den. Analysesvaret bekrefter mistanken om kreft. For å få behandling må hun reise til sykehuset Ocean Road Cancer Institute i hovedstaden. Dette sykehuset er det eneste i landet som tilbyr kreftbehandling med cellegift og strålebehandling. Etter flere dagers ventetid på det overfylte sykehuset får hun komme til en konsultasjon. Når hun endelig får startet cellegiftbehandlingen må hun betale for den selv. Strålebehandling får hun tre ganger $i$ uken, i motsetning til fem behandlinger som er anbefalt for å få en effektiv behandling. Hun rekker å motta to cytostatikabehandlinger før hun dør.

\section{Kreft i Afrika}

Dette er en fiktiv historie, men den kunne veldig gjerne vært sann. Historien illustrerer situasjonen for den kreftsyke pasienten i Tanzania. Verdens helseorganisasjon anslår at i 2020 vil det være 16 millioner mennesker globalt som hvert år får en kreftdiagnose, og 70 prosent av dem vil bo i utviklingsland (1). Dette er en stor økonomisk utfordring for allerede tungt belastete helsevesen i disse landene. Samtidig står de fleste land i Afrika overfor en rekke andre helseutfordringer de må håndtere, med HIV/AIDS, polio og malaria høyt oppe på prioriteringslisten. Kreft kommer derfor i skyggen av disse infeksjonssykdommene, til tross for at statistikk viser at kreft tar flere menneskeliv enn HIV/AIDS, polio og malaria gjør til sammen (2). Tallene forteller hvor viktig det er å rette søkelyset mot kreftsituasjonen i afrikanske land.

\section{Krefttilfellene øker}

Historien om den kreftsyke kvinnen innledningsvis setter et søkelys på noen av de viktigste faktorene som kanskje kan forklare hvorfor kreftstatistikken er så dyster i Afrika. Det at kreft ansees som en relativt ny sykdom i Afrika kan være en av hovedforklaringene $(2,3)$. Siden sykdommen er relativt ny er det en mangelfull bevissthet og forståelse for kreft og kreftens sykdomsforløp i befolkningen $(2,3)$. Dette fører til at man ikke oppsøker lege før symptomene er blitt smertefulle og hemmende i hverdagen. Tradisjonell medisin står sterkt i den tanzanianske kulturen. Når det gjelder kreft er dette et stort problem, da det ofte utsetter det mulige diagnosetidspunktet. Siden pasienten har begrenset kunnskap om kreft, har man ikke forutsetninger for å knytte sammen symptomer og kreftsykdom (4). Når den medisinske hjelpen som blir gitt heller ikke er effektiv, er det nærliggende at man knytter symptomene og sykdommen til overtro og trolldom. Det at pasienten unngår å oppsøke medisinsk hjelp kan også ha en sammenheng med at symptomene på kreft kan ha visse likhetstegn med symptomene på HIV/AIDS, en sykdom som er sterkt stigmatisert.

\section{Mangler kunnskap}

Redusert bevissthet og kunnskap blant helsepersonell er dessverre et av problemene ved krefthåndteringen (4). I pensumet på både medisinstudiet og i sykepleierutdanningen i Tanzania er det lite undervisning om kreft. Det finnes derfor få leger og sykepleiere som har tilfredsstillende kunnskaper om kreftdiagnostisering, behandling og relevant sykepleie. Infeksjonssykdommer er en stor del av hverdagen i Afrika, og antibiotikabruk er omfattende. Dette kan forklare hvorfor helsepersonell i første rekke mistenker infeksjon framfor noe mer alvorlig. Den manglende kunnskapen blant helsepersonell er en viktig grunn til at pasienter ikke får stilt en kreftdiagnose før sykdommen har nådd et langtkommet stadium. Historien om kvinnen illustrerer ulike faktorer som er med på å påvirke sykdomssituasjonen hennes. I ressurssterkere land har man lokale behandlingsinstitusjoner, og det å komme seg dit er ingen betydelig utfordring for pasienten. 


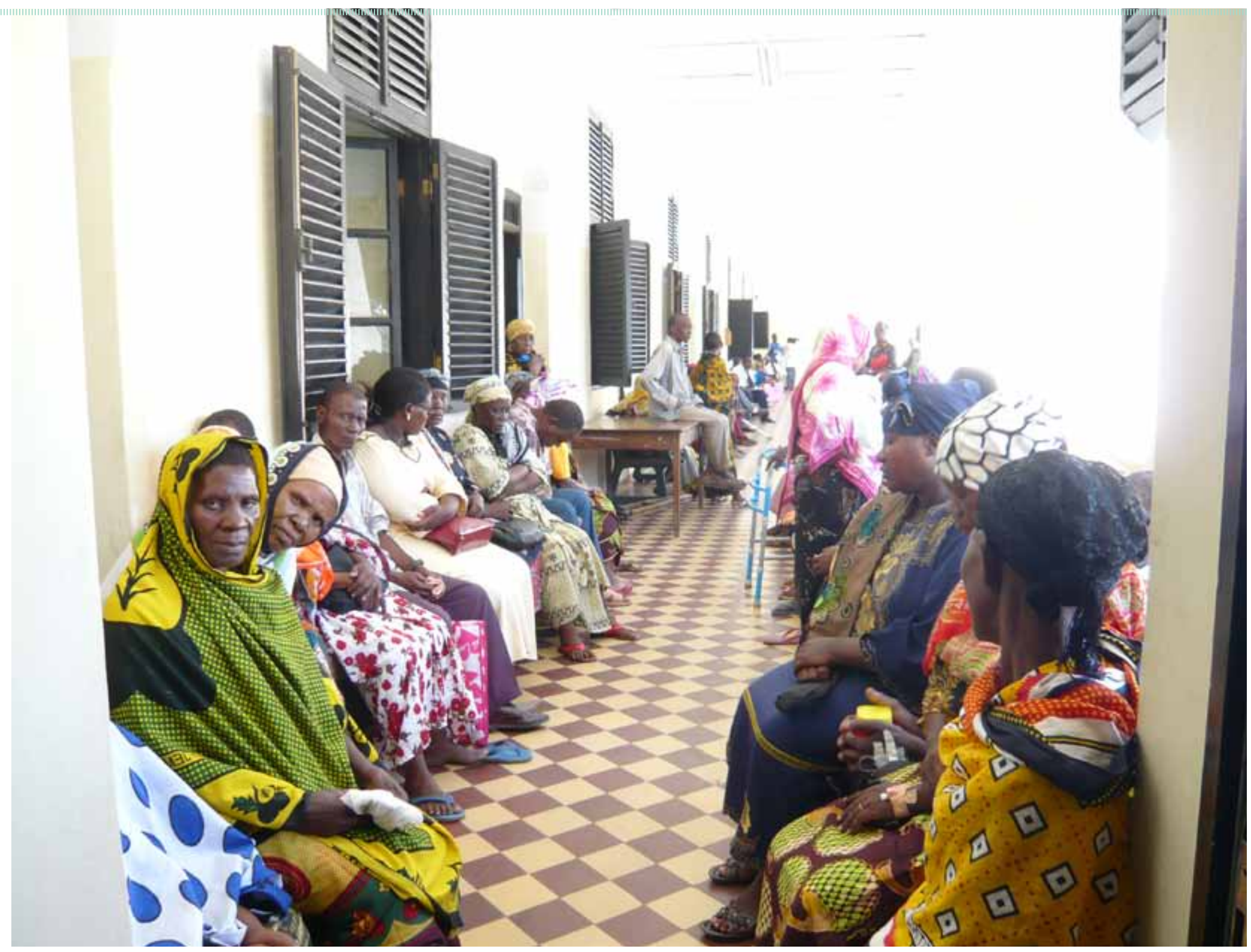

KREFTPASIENTER I Kø: Polikliniske pasienter som venter på behandling ved kreftsykehuset Ocean Road Cancer Institute i Tanzania. Foto: Ellen Tolo.

I land som Tanzania vil den begrensete infrastrukturen spille en rolle i pasientenes sykdomsprogresjon; man må ofte reise langt, veinettet er dårlig, offentlig transport er lite utbygd, og ikke minst, det finnes få behandlingssituasjoner. Sammenlagt gjør disse ulike faktorene sitt til at behandlingsstart utsettes betydelig. Samtidig må pasienten reise fra familien, noe som vil ha store konsekvenser for barna, og ikke minst for familiens økonomi.

\section{Kreftbehandling og ORCI}

Ocean Road Cancer Institute er på det nåværende tidspunkt det eneste sykehuset i Tanzania som tilbyr både kjemoterapi og strålebehandling. Det er et sykehus med 120 senger, men man har jevnt over et belegg på godt og vel 200 pasienter. På grunn av den høye pågangen av pasienter kombinert med begrensete behandlingsressurser, er det mange pasienter som ikke får nødvendig behandling; sykehuset har lite cellegift å tilby, og strålebehandlingen blir ofte ikke gitt regelmessig, hvilket er vesentlig for at behandlingen skal ha tilfredsstillende effekt. Kreftbehandlingen i Tanzania skal i utgangspunktet være gratis, men begrensete statlige midler gis til å dekke behovet for nødvendig og effektiv kreftbehandling. Oftest må pasienten betale deler av, eller i verste tilfelle hele cellegiftbehandlingen sin selv. Strålemaskiner er store økonomiske investeringer, og det koster å holde dem ved like. Ved ORCI har man for øyeblikket tre strålemaskiner. Utfordringen er at sykehuset har problemer med regionale strømbrudd, og manglende økonomiske midler til å vedlikeholde maskinene. Dette resulterer i at en eller flere maskiner kan være ute av drift for kortere eller lengre perioder.

\section{Palliasjon}

Som historien over illustrerer er det et stort problem at den kreftsyke pasienten i Tanzania har en sykdom som har kommet langt før hun eller han får stilt en kreftdiagnose (5). Palliasjon, det å kunne tilby pasienten lindring og en fredfull død, har en sentral rolle i kreftomsorgen. Kreft, og ikke minst langtkommen

\section{Kreft ansees som en relativt ny sykdom i Afrika.}

kreftsykdom, innebærer ofte ubehag og smerter. I Tanzania, hvor mange mennesker lever med ubehandlet eller underbehandlet kreftsykdom, er det av stor betydning for pasienten at palliasjon blir prioritert og tildelt økonomiske midler.

Helsepersonell ved behandlingssentrene i Tanzania uttrykker strekt behov for å kunne tilby bedre palliativ pleie, i form av bedre smertelindring og symptomkontroll. Man ønsker sterkt å utvikle 
en hospitsvirksomhet. Dessverre finnes det for øyeblikket lite $ø$ konomiske midler i Tanzania til å gjennomføre dette. Generelt i Afrika er det lite bruk av morfin, til tross for medikamentets sentrale rolle i palliasjonen (6). I hverdagen på ORCI gir man hovedsakelig paracetamol, tramadol og dexametason, samt i noen tilfeller petidin. Man gir også morfin mikstur (pulver som blandes med vann til styrken $5 \mathrm{mg} / \mathrm{ml}$ ) som inntas per oralt, gjerne i kombinasjon med paracetamol. Morfin som injeksjon blir sjelden gitt, og depottabletter finnes ikke. Sykepleierne opplever ofte at pasientene ikke ønsker å ta morfin, da det fremdeles er et stigmatisert medikament med tanke på rusproblematikk (6). Den kreftsyke pasienten i Tanzania har sjelden noe annet valg enn å bli hjemme, og oftest lide en smertefull død med pårørende som pleiepersonell. Det finnes private organisasjoner som tilbyr senger til mennesker med en langtkommet ondartet sykdom, men dette tilbudet er gjerne forbeholdt AIDS-pasienter.

\section{Forebyggende tiltak}

Man mener at en tredjedel av kreftformene i Afrika kan forebygges (7). Infeksjoner er ansvarlig for nærmere 36 prosent av krefttilfellene i utviklingsland, i motsetning til vestlige land hvor tallet er mindre enn 10 prosent $(5,8)$. Max Parkin et al. påpeker at kreftbyrden er stigende som et resultat av økende HIVassosierte kreftformer, som livmorhalskreft og Kaposis sarkom

\section{Flere av de hyppigste kreftformene kan unngås gjennom forebyggende tiltak.}

(5). Man ser også at tallene er stigende for kreftformer knyttet til livsstilsendringer assosiert med økonomisk utvikling, og en $ø$ kende aldrende befolkning. Disse tallene viser hvor viktig det er å fokusere på forebyggende arbeid i afrikanske land. Å forebygge kreftsykdom har en stor økonomisk gevinst framfor å behandle kreft $(6,9,10)$. I land som Tanzania, med begrensete økonomiske ressurser, vil det derfor være hensiktsmessig å fokusere på forebygging. Flere av de hyppigste kreftformene kan unngås gjennom forebyggende tiltak. Blant den afrikanske befolkning har den økende urbanisering og modernisering innvirkning på livsstilen (3), og livsstilsendringene dette medfører har betydning for risikoen for å utvikle kreftsykdommer. Lungekreft er sterkt assosiert med bruken av tobakk $(10,1)$. Med et fallende forbruk i den vestlige delen av verden har tobakksindustrien kastet seg over Afrika, med det resultat at det blir stadig flere røykere i verdensdelen (10). Undervisning- og holdningskampanjer, som gjør befolkningen bevisst på hvor farlig tobakk er, vil være av stor betydning (11). Undervisningskampanjer om kosthold, samt å hindre eksponering av kreftrelaterte infeksjoner, behandling av slike infeksjoner og vaksinering mot spesifikke infeksjoner, vil kunne være utslagsgivende for hvor mange som utvikler kreft i afrikanske land.

\section{Screening}

Forskning bekrefter at nasjonale screeningprogrammer med celleprøver er en effektiv strategi for å oppdage livmorhalskreft på et tidlig stadium $(5,12)$. Denne sykdommen er den ledende dødsårsaken blant kvinner i utviklingsland $(12,13)$, og er også den hyppigste kreftformen blant kvinner i Tanzania. I Dar es Saalam har det blitt satt opp plakater i boligområder og reklame på radio oppfordrer kvinner til underlivsundersøkelse med celleprøve. Kreftavdelingen ved det regionale sykehuset i Mwanza ønsker å starte en flytende klinikk på Victoriasjøen slik at man kan oppsøke kvinner i lokalmiljøet. Screening er et eksempel på hvordan det er mulig å diagnostisere pasienten før de har nådd et avansert stadium, og hvordan en hyppig kreftform kan forebygges. Et annet forebyggende tiltak mot livmorhalskreft er vaksinen som beskytter kvinner/jenter mot utviklingen av det kreftfremkallende viruset HPV. Vaksine er et tiltak som vil være av stor gevinst for kvinners helse, og redde mange liv (1). Utfordringen er at vaksinen er kostbar, og det er vanskelig å sette i gang effektiv vaksinasjon i Tanzania uten tett samarbeid med legemiddelindustrien $(1,4,14)$.

\section{Betydningen av kunnskap}

Kunnskap om kreftsykdom er avgjørende, noe den innledende historien tydeliggjør. Å heve kunnskapsnivået blant helsepersonell vil bety mye for den kreftsyke pasienten i Tanzania, og ikke minst for dem som ennå ikke har fått sin kreftdiagnose. Kunnskapsutveksling og erfaringsoverføring mellom institusjoner er en god måte å heve det faglige nivået på, og lite ressurskrevende. I de senere år ser man at flere sykehus i ulike afrikanske land inngår samarbeid med sykehus i asiatiske land, hvor særlig India er fremtredende. Det er også viktig at kunnskapsutveksling skjer mellom ressurssterkere og ressurssvakere land innad i Afrika, da man har mye av de samme sykdomsutfordringene. Jeg vil påstå at de veletablerte kreftinstitusjonene i den vestlige og ressurssterkere delen av verden har et moralsk ansvar for å hjelpe og støtte kollegaer med å utvikle kreftomsorgen. Fordelen med utvekslingsprosjekter er at det ikke er økonomiske midler som blir overført, men det blir utvekslet kunnskap mellom helsepersonell. I land hvor korrupsjon er et fremtredende problem vil det være svært hensiktsmessig at midler blir gitt på andre måter enn direkte pengeoverføringer. I samarbeid med Fredskorpset har Haukeland universitetssjukehus i Bergen et utvekslingsprogram med Ocean Road Cancer Institute i Tanzania. I dag er dette et utvekslingsprogram innen sykepleie, hvor det er to sykepleiere fra Tanzania i Norge, og to sykepleiere fra Norge i Tanzania. Prosjekter som dette øker norske sykepleieres bevissthet om den prekære situasjonen i kreftomsorgen, og det skaper engasjement og vilje til å gjøre noe for situasjonen. Tanzanianske sykepleiere ved et norsk sykehus opplever en hverdag med et mangfold av ressurser, men med strengere rutiner. Ved å jobbe i en norsk sykehussetting innarbeider den tanzanianske sykepleieren nye rutiner. Den nye erfaringen vil hun eller han ta med seg hjem, og prøve å kombinere med hverdagen på det tanzanianske sykehuset. Ved å jobbe under andre forhold ser man tydeligere små forandringer som kan gjøres, som til tross for at de er små kan være av stor betydning. I tillegg til utveksling kan også kortere opplærings- og praksisprogrammer for helsearbeidere, med spesialiserte helsepersonell som veiledere og forelesere være et viktig bidrag for å øke kunnskapsnivået.

\section{Politisk initiativ}

Den enkelte regjering i de afrikanske landene må ha politisk vilje og ta initiativ i forhold til den brutale kreftsituasjonen i Afrika. Man må anerkjenne kreft som et stort - og økende - problem. Den enkelte stat må ha vilje til å utvikle et kreftkontrollprogram og engasjere seg aktivt for å implementere programmet i samfunnet (1). Innebygd i programmet må det være en nasjonal handlingsplan for det forebyggende arbeidet, diagnostikk og behandling av kreft, og en nasjonal målsetting for kreftomsorgen med utgangspunkt i tilgjengelige ressurser. Forskning bør være en del av kreftkontrollprogrammet. Forskning er viktig 
for å evaluere tiltakene og se om de gir positive resultater, eller for å undersøke om man må forandre tiltakene. Finansiering er nevnt flere ganger som en vesentlig utfordring. Dr. Ngoma ved Ocean Road Cancer Institute, viser til at kun 5 prosent av de globale midlene som brukes på kreft, blir brukt til dette formålet i utviklingsland (14). Det internasjonale samfunnet har derfor en moralsk plikt til å engasjere seg i den prekære situasjonen i Afrika $(3,4)$. Viktige organisasjoner, slik som Verdensbanken og University of Oxford, er allerede engasjerte i dette. WHO spiller her en sentral rolle. Det at organisasjoner, både statlige og private, og ikke minst legemiddelindustrien, tilbyr politisk, teknisk og økonomisk støtte vil kunne gjøre mye for kreftsituasjonen i Afrika $(1,14)$.

\section{Veien videre}

Kreft er et tema som har kommet i skyggen av det generelle sykdomsbildet i Afrika. Det skjer til tross for at denne delen av verden har det største antallet nye tilfeller av kreft. Veletablerte kreftinstitusjoner, organisasjoner og kreftsentre kan bidra i utviklingen av nasjonale kreftkontrollprogrammer i land med store økonomiske utfordringer. Med det vil man kunne oppnå en økt bevissthet på kreft, og anerkjennelse av kreft som et samfunnsproblem. Overføringer av ressurser, det være seg økonomiske eller kunnskapsbaserte, bør tilbys med utgangspunkt i landets egne behov og ønsker for bruk. Man bør ta hensyn til at løsninger som fungerer i europeiske land, ikke nødvendigvis vil være hensiktsmessige i et afrikansk land. Gjennom økt bevissthet om kreft og symptomer på kreft blant helsepersonell og befolkningen generelt, vil kreftsykdommen kunne oppdages på et tidligere stadium, prognosene være bedre, behandlingen mindre komplisert, og sannsynligheten for helbredelse større. Man vil også kunne forebygge antallet nye krefttilfeller. Den palliative delen av kreftomsorgen må ikke falle i skyggen. En god palliativ omsorg med smerte- og symptomkontroll forbedrer livskvaliteten til pasienten og familien som står overfor store utfordringer knyttet til kreftsykdommen (9). Situasjonen når det gjelder kreft i Afrika er prekær, og det å øke bevisstheten rundt dette problemet vil forhåpentligvis være første steg på veien mot at flere engasjerer seg i kampen mot kreft på det afrikanske kontinentet. IIII

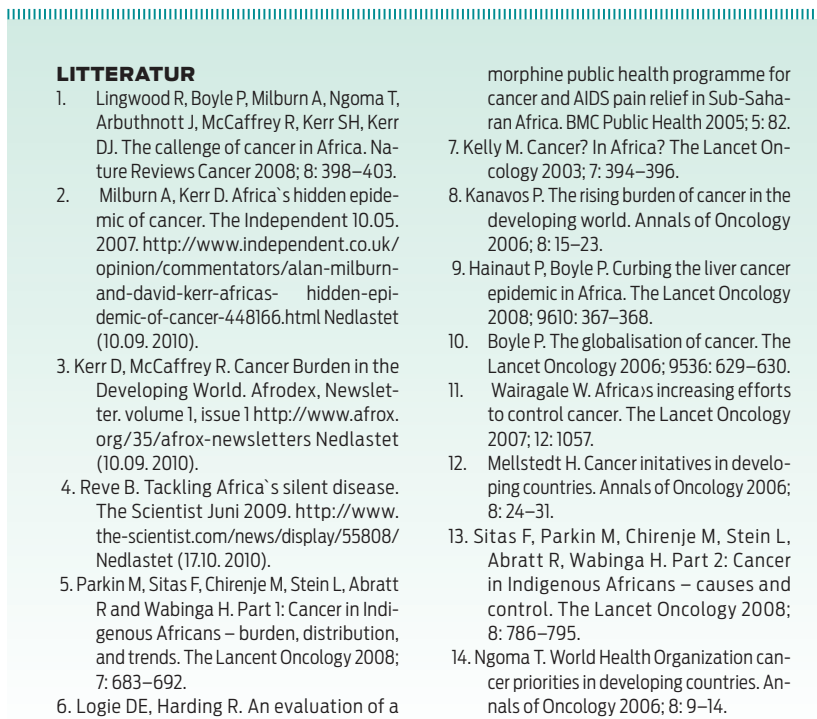

\title{
Reiser ut for å lære
}

\author{
Å sende sykepleiere til Afrika bygger kompetanse \\ i Helse Bergen. Tekst Nina Hernæs Foto Marit Fonn
}

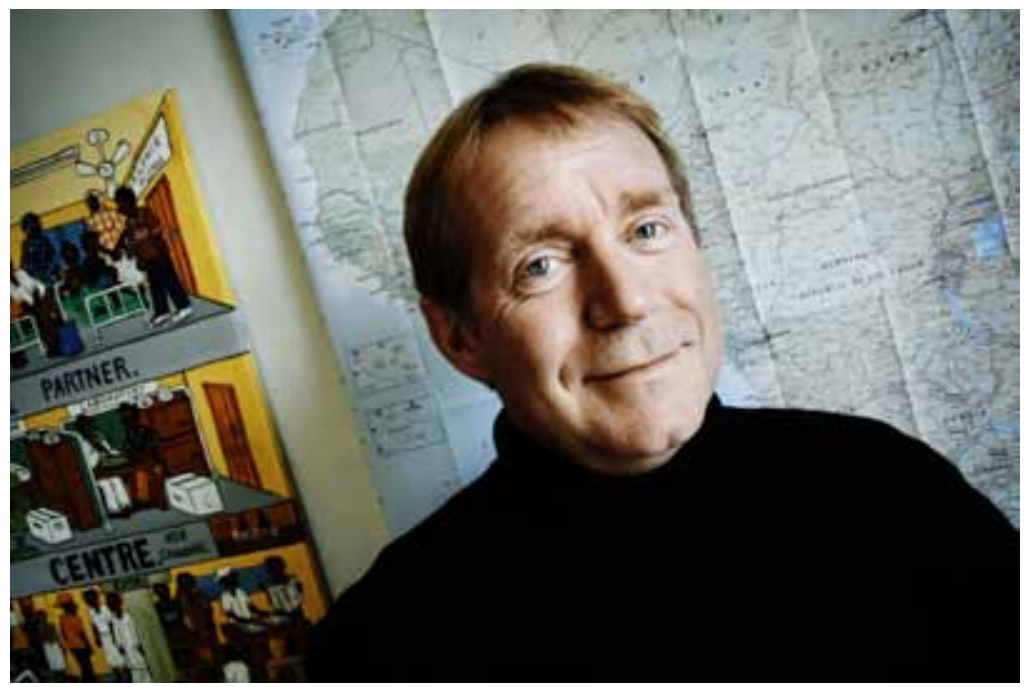

MYE Å HENTE: Jon Wigum Dahl mener Helse Bergen får mye igjen for å engasjere seg i fattige land.

E llen Tolo, som har skrevet artikkelen om kreft i Tanzania, er en av flere sykepleiere i Helse Bergen som har vært i Afrika. Helse Bergen har en egen avdeling for internasjonalt samarbeid, og har partnerskap med sju sykehus i Afrika og Asia, blant annet i Etiopia, Sør-Sudan og India. Til nå har avdelingen vært selvfinansiert.

- Men vi ser at våre ansatte lærer så mye ute, at Helse Bergen i år har bevilget oss 3,5 millioner kroner, sier avdelingsleder Jon Wigum Dahl.

Etter planen vil bevilgningen øke til 7 millioner i 2012 og 10 millioner årlig fra og med 2013.

- Pengene skal først og fremst brukes til kompetansebygging internt.

\section{God trening}

- Det har bredt seg en forståelse i organisasjonen om at samarbeid med afrikanske sykehus ikke bare handler om å hjelpe noen det er synd på, men at vi har mye å lære selv også, påpeker Dahl.

- Det gjør også noe med verdigheten til dem vi samarbeider med.

Flere hundre ansatte har deltatt i ulike programmer siden avdelingen ble opprettet i 2003. Akkurat nå er sju sykepleiere enten reist ut eller er på vei.

Dahl viser til at land i for Afrika og Asia har et helt annet sykdomsbilde enn Norge.

- Det gir kunnskap og også mulighet for mengdetrening. For eksempel har vi en hjertelege som snart skal til India. Mens vi her i Bergen har femseks pasienter med mitralstenose i året, har de der fem-seks slike pasienter i uken. Ved å sende en lege dit, bidrar vi med kompetanse. Men vi får også bedre kompetanse tilbake, sier han.

\section{Beholder grunnlønnen}

Midlene fra Helse Bergen gjør også at de som reiser ut, får beholde grunnlønnen sin.

- Alle avtaler gjelder og de beholder ansettelsesforholdet sitt her, sier Dahl.

- Dette er et viktig prinsipp både for ledelsen og fagforbundene.

Han ser bare positive ringvirkninger av det internasjonale engasjementet.

- Dette skaper entusiasme, både blant medarbeidere og i lokalsamfunnet. Det fremmer samarbeid på tvers av faggrupper og gir sykehuset positiv oppmerksomhet, sier han. IIII 